\title{
PROCESSING AND PRESERVATION OF OKRA PICKLE
}

\author{
M. M. Hosain, R. Jannat, M. M. Islam ${ }^{1 *}$ and M. K. U. Sarker ${ }^{2}$ \\ Faculty of Agro-industrial and Food Process Engineering, Hajee Mohammad Danesh \\ Science and Technology University (HSTU), Dinajpur, Bangladesh
}

\begin{abstract}
The fresh okras were analyzed for proximate composition whereas the developed pickles were analyzed for proximate composition, microbiological status, sensory attributes and overall storage stability of the pickles. The proximate composition fresh okra was moisture $87.5 \%$, ash $0.89 \%$, total solid $18 \%$, vitamin-C $11.1 \mathrm{mg} / 100 \mathrm{~g}$. According to the processing method, the compositions of developed pickles were different. The range of moisture content varied from $59.28 \%$ to $69.20 \%$ for pickle in sugar, oil and combination of both. Since sugar and salt were used, resulting losses in moisture content were observed in all the samples. Vitamin-C content was decreased or lost by oxidation and heat following first-order kinetics which states that concentration has exponential relationship with time. The microbiological studies revealed that total viable counts (bacteria) were high in pickles which was processed in sugar and low which was processed in oil and oil-sugar mixed, respectively. The acceptability of processed pickles was organoleptically evaluated by the panelists using 1-9 hedonic scale assigned marks for colour, flavour, texture and overall acceptability. The test score indicated that among three samples, the pickle which was processed in sugar and oil mixed (sample-3) was the most acceptable. Storage studies were carried out for up to six months at room temperature $\left(27^{\circ} \mathrm{C}-33^{\circ} \mathrm{C}\right)$ at an interval of 1 month up to first 2 months and at an interval of 2 months for the consecutive 4 months. The result showed that moisture content decreased slightly with time. All the pickles became softer with the passing of time.
\end{abstract}

Key Words: Okra pickle, Processing, Preservation

\section{INTRODUCTION}

Okra (Hibiscus esculentus), also known as gumbo, bamya, bindi, bhindi, bamies, and ladies' fingers; is a member of the cotton (Mallow) family. It is grown well in South America, West Indies, and India; used in soups and stews. Okra is a rich source of vitamin $C$, calcium, carotene, vitamin $B_{1}$, and foliates, contains dietary fibre.

\footnotetext{
1 Assistant Professor, Department of Agricultural and Industrial Engineering, HSTU, Dinajpur, Bangladesh

2 Professor, Dept. of Agricultural and Industrial Engineering, HSTU, Dinajpur, Bangladesh

*Correspondence: mmi_hstu@yahoo.com
} 
Bangladesh is predominantly an Agricultural country where agriculture contributes about $23.5 \%$ of GDP (BBS, 2006 and Handbook Agricultural Statistics, MoA). Vegetables are considered as one of the most important groups of dietary food crops due to their higher nutritive value, and yield. In Bangladesh daily per capita availability of vegetables excluding tuber crops is only $52 \mathrm{~g}$ against the required amount of $200 \mathrm{~g}$ (Ali, K. et al., 1992). About 24,230 metric tons of okra is produced from 7152 hectares of land per year in Bangladesh, (BARI, 2010). About $90 \%$ of the total okra is produced within four months (May to August) only. The farmers have to sell their vegetables with low price at the harvesting time due to lack of processing and preservation knowledge. But if we can apply the proper technology to preserve these vegetables, we can ensure to supply these vegetables throughout the year. It can help the nation to get rid from malnutrition as well as the farmers can be benefited financially.

There are a number of methods for the preservation of perishable items. Pickling is one of them. Though the preservation of vegetables and fruits in pickled form began as a house hold art. At present most of the world's supply of pickles is produced in commercial plants.

When any food (fruits, vegetables, fish or meat) is preserved by natural salt or vinegar or oil or spices, then the processed food is called pickles. Pickles are widely acceptable and usable food item in Bangladesh as well as over the world.

Pickling with the help of vinegar and oil has been practice from time immemorial in this country. If these preservatives are used in proper proportions the pickles can be retained for 10-15 years without spoilage. In modern days pickles are prepared with salt, oil, vinegar, mixture of salt and spices (Srivastava et al., 2002)

A number of fruits and vegetables are preserved in vinegar, e.g. mango, garlic, chillies etc the vinegar in which these things are preserved should contain good percentage of acetic acid. These can also be preserved in 5\% acetic acid solution (Binsted et al., 1962).

Pickles are generally consumed by every one whether a child or old, a labor, or a rich man. The pickle makes the dish or food taste better. The pickle generally acts as appetizer. The assimilation of gastric is better thereby improving the digestion. Various types of fruits and vegetables are used in the preparation of pickles with high export potential, it is necessary to manufacture these products as per the stipulated standards. The popular common pickles manufactured by various industries and available in our market are mango pickle, olive pickle, garlic pickle, brinjal pickle, mixed fruit and so on. But the qualities of these pickles are of question.

Therefore, the study was undertaken to asses the proximate composition of fresh okra and okra pickles, processing of okra pickles with different recipes, to study the self life in two different temperatures (room and refrigeration) and to asses the overall acceptability of the processed pickles. 


\section{MATERIALS AND METHODS}

The study was conducted in the laboratory of the Department of Food Processing and Preservation, Department of Food Engineering and Technology and the Department of Food Science and Nutrition under the Faculty of Agro-Industrial and Food Process Engineering, Hajee Mohammad Danesh Science and Technology University, Dinajpur, Bangladesh.

The Okra and other raw materials were collected from local market. The glass bottles and other chemicals required for processing of products were used from the laboratory. Fresh okra had washed thoroughly and these were cut into small pieces up to 0.5-1 inch. Then the okra was blanching at $75^{\circ} \mathrm{C}$ for 15 minutes. After proper processing they were filled into glass jars and pieces of okra was become soft and turned into light brown.

The experiment was conducted with 3 (three) samples which are as follows :

Sample-1 (101) : Okra pickle with oil and sugar mixed based.

Sample-2 (202) : Okra pickle with sugar based.

Sample-3 (303) : Okra pickle with oil based.

Table 1. Different recipes of okra pickles

\begin{tabular}{lcccc}
\hline \multicolumn{1}{c}{ Ingredients } & Sample-1 (101) (g) & Sample-2 (202) (g) & Sample-3 (303) (g) \\
\hline Okra (Ladies finger $)$ & 500 & 500 & 500 \\
Garlic & 150 & 500 & 150 \\
Ginger & 150 & 50 & 150 \\
Turmeric & 10 & - & 10 \\
Red chili powder & 15 & 10 & 15 \\
Joyfall & 5 & - & 5 \\
Sugar & 250 & 500 & - \\
Methi & 3 & - & 3 \\
Postadana & 15 & - & 15 \\
Mustard oil & 350 & - & 350 \\
Mustard seed & 5 & - & 5 \\
Cumin & 5 & - & 5 \\
Vinegar & $75 \mathrm{ml}$ & $150 \mathrm{ml}$ & $75 \mathrm{ml}$ \\
Sodium Benzoate & 0.5 & 0.5 & 0.5 \\
Spices & - & 10 & - \\
\hline
\end{tabular}

\section{Chemical analysis}

The raw and processed samples were analyzed for their moisture, ash, titrable acidity, $\mathrm{pH}$, total soluble solids and vitamin-C. All the determinations were done in triplicate and the results were expressed as mean value as per methods of AOAC (1984). 


\section{Microbiological examination}

For total viable count of microorganism present in okra pickles, standard plate count method was followed according to the method described in "Recommended method for the microbiological examination of food" American Public Health Association (1967).

\section{Sensory evaluation}

The consumer's acceptability of developed pickles was evaluated by a taste-testing panel. The hedonic rating test was used to determine this acceptability. The panelists were selected form the teachers and students of the faculty of Agro-Industrial and Food Process Engineering, Hajee Mohammad Danesh Science and Technology, Dinajpur. Samples were served to the panelists and were asked to assign appropriate score for characteristics colour, flavour, texture and overall acceptability of processed okra pickles.

The scale was arranged such that:

$9=$ Like extremely, $8=$ Like very much, $7=$ like moderately, 6 =like slightly, $5=$ Neither like or dislike, $4=$ Dislike slightly, $3=$ Dislike moderately, $2=$ Dislike very much and $1=$ Dislike extremely.

The results were evaluated by Analysis of variance and Duncan's New Multiple Range Test Procedures of the Statistical Analysis System (SAS, 1985).

\section{Storage studies:}

The pickles were stored at room temperature. The different parameters of assessing the deterioration of the products were observed at a regular interval of 1 month up to two months and at an interval of two months for the next four months. The coloue, flavour, texture, moisture content, acidity and visual fungal growth etc. were observed up to the whole storage periods.

\section{RESULTS AND DISCUSSION}

The experiment was conducted to determine the effective means of processing and preservation of okra in the time when it is available to use at the off-season when price is significantly higher than the growing season. The study is also to investigate the cost analyses on home made processing industry.

Table 2. Chemical composition of fresh okra and okra pickles

\begin{tabular}{l|c|c|c|c|c}
\hline \multicolumn{1}{c}{ Sample code } & $\begin{array}{c}\text { Moisture content } \\
(\%)\end{array}$ & $\begin{array}{c}\text { Total solid } \\
(\%)\end{array}$ & $\begin{array}{c}\text { Ash } \\
(\%)\end{array}$ & $\begin{array}{c}\text { Fat } \\
(\%)\end{array}$ & $\begin{array}{c}\text { Vitamin C } \\
(\mathrm{mg} / 100 \mathrm{~g})\end{array}$ \\
\hline Fresh okra & 87.5 & 18 & 0.89 & 0.2 & 11.1 \\
101 & 62.35 & 32.2 & 1.7 & 2 & 2.20 \\
202 & 69.20 & 25.5 & 1.65 & 0.2 & 2.01 \\
303 & 59.28 & 29.4 & 1.8 & 5 & 2.50 \\
\hline
\end{tabular}


The moisture, protein, fat, carbohydrates, ash and vitamin $\mathrm{C}$ in fresh okra was found $89.6 \%, 1.9 \%, 0.2 \%, 6.4 \%, 0.92 \%$ and $13 \mathrm{mg} / 100 \mathrm{~g}$ respectively (Srivastava et al. 2002). The percentage of moisture, ash, acidity and vitamin $\mathrm{C}$ were observed in the present study the result were very close to those reported by Srivastava et al. (2002). The chemical composition of okra pickles varies to a little bit depending on the media at which okra are processing. This may also differ due to climatic condition, growing season, intercultural operations involved, varieties and stage of maturity as well.

Very few literatures are available on composition of fresh okra and okra pickles. So it is very difficult to compare the proximate composition of the fresh and the processed products.

\section{Microbiological study of shelf-stable lemon pickles}

This study was performed by standard plate count (S.P.C) method. The total viable bacterial load was not uniform. The total bacteria were counted as total number of bacteria per gm of sample. The total no. of viable bacteria was counted by multiplying the colony forming unit (cfu) with dilution number. The total numbers of viable bacteria in different samples at different storage period and variation of bacterial load in different okra pickles sample 303 showed minimum count and sample 202 showed maximum count.

Desrosier (1977) reported that pickle products would deteriorate quickly. In general, protection is necessary against the action of moulds, which metabolize the acid developed, paving the way for the advance of other microorganisms. In cold storage fermented and pickled foods could be expected to remain stable for several months.

The covering oil and sugar as well as salt prevent microbial contamination. Usha Rani et al. (1992) found that the safe moisture content in mango pickles to be as high as $61.0 \%$ which is closed to the result obtained for okra pickles. Lower moisture content means higher amounts of nutrients. This fruit contains an appreciable amount of ascorbic acid $(41 \mathrm{mg} / 100 \mathrm{~g})$ which is very important for proper nourishment and maintenance on healthy teeth.

\section{Sensory evaluation of Okra pickles}

The mean scores for colour, flavour, texture and overall acceptability of okra pickles are presented in Table 3.

Table 3. Mean sensory score of okra pickle

\begin{tabular}{c|c|c|c|c}
\hline \multirow{2}{*}{ Sample code } & \multicolumn{4}{|c}{ Sensory attributes } \\
\cline { 2 - 5 } & Colour & Flavour & Texture & Overall acceptability \\
\hline 101 & $8.0^{\mathrm{a}}$ & $8.10^{\mathrm{a}}$ & $7.80^{\mathrm{a}}$ & $8.10^{\mathrm{a}}$ \\
202 & $6.5^{\mathrm{b}}$ & $6.20^{\mathrm{c}}$ & $7.70^{\mathrm{a}}$ & $6.90^{\mathrm{b}}$ \\
303 & $7.5^{\mathrm{a}}$ & $6.30^{\mathrm{b}}$ & $7.50^{\mathrm{a}}$ & $6.30^{\mathrm{b}}$ \\
\hline
\end{tabular}


Sample means having the same letter suffix do not differ at $5 \%(\mathrm{P}<0.05)$ level of statistical significance.

A two-way analysis of variance (ANOVA) was carried out for colour preference and result revealed that there was slightly significant $(\mathrm{P}>0.05)$ difference in colour acceptability among all the samples. As shown in table mean scores suffixed for sample 202 is the lowest value than others. So this indicates that the colour of sample 101 and 303 are more acceptable than other.

\section{Storage studies of okra pickles}

Three different samples of each pickle were used for storage studies at room temperature $\left(27^{\circ} \mathrm{C}-33^{\circ} \mathrm{C}\right)$ from $0-5$ months. The effect of storage time $(0,1,2,4$ and 5 months) on physical properties such as colour, flavour and texture of the pickles were studied and resented as Table 4.

Table 4. Storage Studies of okra pickles

\begin{tabular}{|c|c|c|c|c|c|c|}
\hline $\begin{array}{l}\text { Storage period } \\
\text { (month) }\end{array}$ & $\begin{array}{c}\text { Sample } \\
\text { code }\end{array}$ & Colour & Flavour & Texture & $\begin{array}{l}\text { Visual fungal } \\
\text { growth }\end{array}$ & Remarks \\
\hline \multirow[t]{3}{*}{0} & 101 & No change & No off flavour & Firm & No growth & Good \\
\hline & 202 & No change & No off flavour & Firm & Do & Good \\
\hline & 303 & No change & No off flavour & Firm & Do & Good \\
\hline \multirow[t]{3}{*}{1} & 101 & No change & No off flavour & Slightly soft & Do & Good \\
\hline & 202 & No change & Off flavour & Slightly soft & Do & Good \\
\hline & 303 & No change & No off flavour & Slightly soft & Do & Good \\
\hline \multirow[t]{3}{*}{2} & 101 & No change & No off flavour & Soft & Do & Good \\
\hline & 202 & Change & Off flavour & Slightly soft & Do & Good \\
\hline & 303 & No change & No off flavour & Soft & Do & Good \\
\hline \multirow[t]{3}{*}{3} & 101 & No change & No off flavour & Soft & Slightly growth & Good \\
\hline & 202 & Change & Off flavour & Slightly soft & Do & $\begin{array}{l}\text { Slightly } \\
\text { spoiled }\end{array}$ \\
\hline & 303 & No change & No off flavour & Soft & Do & Good \\
\hline Storage period & $\begin{array}{c}\text { Sample } \\
\text { code }\end{array}$ & Colour & Flavour & Texture & $\begin{array}{l}\text { Visual fungal } \\
\text { growth }\end{array}$ & Remarks \\
\hline \multirow[t]{3}{*}{4} & 101 & No change & No off flavour & Extremely soft & Slightly growth & Good \\
\hline & 202 & Change & Off flavour & Slightly soft & $\begin{array}{l}\text { Excessive } \\
\text { growth }\end{array}$ & Spoiled \\
\hline & 303 & No change & No off flavour & Extremely soft & Slightly growth & $\begin{array}{l}\text { Slightly } \\
\text { spoiled }\end{array}$ \\
\hline \multirow[t]{3}{*}{5} & 101 & No change & No off flavour & Extremely soft & Slightly growth & Good \\
\hline & 202 & Change & Off flavour & Slightly soft & $\begin{array}{l}\text { Excessive } \\
\text { growth }\end{array}$ & Spoiled \\
\hline & 303 & No change & No off flavour & Extremely soft & Slightly growth & $\begin{array}{l}\text { Slightly } \\
\text { spoiled }\end{array}$ \\
\hline
\end{tabular}


Kumar (1985) reported that pickles would be assessed after six months storage in jars for keeping quality, taste and flavor. The pickles became soft after three months, but otherwise remained satisfactory up to 6 months of storage.

\section{Cost analysis}

Table 5. Cost analysis of okra pickle production

\begin{tabular}{l|cc|c}
\hline \multicolumn{1}{c|}{ Item } & Price in (Tk) & Item & Price in (Tk) \\
\hline Okra (200g) & 1 & Electricity (1 units) & 3 \\
Mustered oil $(75 \mathrm{ml})$ & 8 & Labour (1 hour) & 5 \\
Chemicals & 4 & Packaging & 3 \\
Spices & 4 & Fixed cost $(40 \%$ of total cost $)$ & 12.5 \\
\hline \multicolumn{2}{l}{ Total } & & 40.50 \\
\hline
\end{tabular}

The cost per bottle (100g) of okra pickle is Tk. 20.25, but the cost per bottle will be lower when it was produced in large scale. The production cost of okra pickle depends on market value of raw material and proper management.

\section{CONCLUSION}

Okras are mainly used as vegetables but like other developed countries they may be turned to delicious and salad crops. During growing season farmers are bound to sell their produce at a very low price. But if farmers can preserve their produce by effective and economic way, they will be able to get proper price and encouraged to maximize production. Processing and preservation by pickling may be used for large scale and small industries. Commercial and home scale processing by pickling may also be effective. Thus, a large number of skilled and semi-skilled, even unskilled persons would be employed in the relevant industries, which will help to remove unemployment problem of our country. Processed products can be sold at high price in off-season in both local and foreign exchange which will enrich our national economy. Furthermore, since farmer would get proper price for their produce, productivity would be increased and sustained.

\section{REFERENCES}

Ali, K., Malek, M. A. Khurshid, J. and Salamat, U. K. 1992. Nutrient content of food and nutrition, University of Dhaka, Bangladesh. pp. 18-20.

AOAC. 1984. Official Method of Analysis 12th edn. Association of Official Agricultural Chemist, Washington, DC. USA.

APHA. 1967. Recommended method for the microbiological examination of food" American Public Health Association. 800 Street, NW Washington, DC. USA. 
BARI, 2010, Modern Varieties, their characteristics and Improved Production Technology of Okra, Bangladesh Agriculture Research Institute.

BBS, 2006. Handbook Agricultural Statistics, Ministry of Agriculture (MoA), Bangladesh.

Binsted, R., Devy, J. D. and Dakin J. C. 1962. Spices and flavourings for pickle and sauce product. Pickle and sauce making. Food Trade Press Ltd, London. pp. 25-28.

Desrosier, N. W. 1977. The Technology of Food Preservation. The AVI pub. Co. $2^{\text {nd }}$ Ed. West Port USA. pp. 340-349,364.

Kumar, P.1985. Watermelon- Utilization of peel waste for pickle processing. Indian Food Packer. 9(40): pp. 49-52.

SAS. 1985. SAS user guide. Statistics, version $5^{\text {th }}$ ed. SAS Institute. Inc. Cary, NC.

Srivastava R.P. and Kumar, S. 2002. Fruits and vegetable Preservation, Third edition. International Book Distributing Co. Lucknow-226004, India.

Usha Rani, M., Rama Rao, S. N., Giria Bai, R., Nagaraja, K. V. 1992. Studies on quality standards of Indian commercial pickle. Indian Food Packer, 46(6): 27-33. 